\title{
Major Challenges Faced By Intern Radiographers in Northern Nigeria
}

\author{
Obotiba A.D ${ }^{1}$., Abubakar Sahabo ${ }^{1}$, Nwobi I.C ${ }^{1}$., Abubakar A ${ }^{1}$., Abubakar M.G ${ }^{1}$, \\ Luntsi $G^{1}$., Nkubli F.B ${ }^{1}$., Njiti $M^{1}$, Unanam ES ${ }^{2}$, Ayankunle $F^{3}$. \\ ${ }^{I}$ (Department of Radiography, College of Medical Sciences, University of Maiduguri, Nigeria) \\ ${ }^{2}$ (Faculty of Veterinary Medicine, University of Maiduguri, Nigeria) \\ ${ }^{3}$ (School of Health Technology, Lafia, Nasarawa State, Nigeria)
}

\begin{abstract}
Study is aimed at identifying challenges faced by intern radiographers in Northern Nigeria. A univariate descriptive survey was adopted. Intern Radiographers in hospitals in Northern Nigeria were invited to complete questionnaire purposely designed to assess challenges involving their training/practice, welfare and mentorship. Also a standard interview guide was for used the chief interns of participating hospitals to assess facilities, manpower, and practice. Data was analyzed using SPSS version 16.0. A total of 55 questionnaires were distributed, out of which 50 were returned filled, providing a return rate of $85.7 \%$. Challenges faced include; interns (34\%) spending 8-14 months from graduation before securing a placement, lack of proper orientation by hospital management at commencement (72\%), inadequate supervision (73\%), no radiation monitoring devices provided (60\%), lack of accommodation (60\%), poor response of managements to welfare (40\%) and lack of functional radiologic equipment with few senior ranking clinical radiographers in the region $(21.9 \%)$. The study reveal that the major challenges faced by intern radiographers in this region are interrelated, which are inherent in training/practice, and mentorship. The major challenge faced was poor mentorship programme. A more robust periodic monitoring of centers by regulatory body was identified as the panacea for practice improvement.
\end{abstract}

Keywords: Challenges, Intern, Intern Radiographer

\section{Introduction}

Radiography is the art and science involving the use of different forms of radiant energy for the purposes of diagnosis and therapy [1]. Radiography is practiced by someone trained in an approved and accredited institution and licensed by a designated authority/regulatory body of the country where the individual wishes to practice. Each country has its own regulatory body like the Radiographers Registration Board of Nigeria (RRBN) in Nigeria. Others include; Health and Care Professions Council (United Kingdom), Australian Institute of Radiography, American Registry of Technologists, Canadian Association of Medical Radiation Technologists (CAMRT) etc.

RRBN was established by Decree No. 42 of 1987, now Cap R1 Laws of the Federal republic of Nigeria 2004. This is the regulatory body tasked with determining the standards of knowledge and skills that should be attained by persons seeking to become members of the profession. The board also maintains a register of members of the profession and publish from time to time list of licensed persons [2]. For an individual to practice radiography in Nigeria, the individual needs to undergo a formal radiography related university education [1]. On graduation, each candidate is inducted by RRBN and is allowed to undergo one year internship program in any hospital approved by RRBN.

Therefore, internship is a supervised practical training undertaken by a students or recent graduate with an emphasis on the job training rather than merely employment [3]. This training period was introduced in the health sector due to the low clinical practice experienced by health graduates. In other words, internship aims to develop a practical experience for beginners in an occupation or profession by providing a supervised practical training. Radiography graduates undertake the internship as 48 full time equivalent weeks of professional clinical practice. With 40 working hours per week and on call duties. During this period it is expected that a radiography graduate would experience and subsequently perform a range of clinical procedures as they progress towards independent practice. These clinical procedures include; skeletal radiography, plain radiography of viscera and soft tissues, contrast agent examinations, dental radiography, paediatric radiography, ward radiography, procedures in the operating theatre, computerized tomography, ultrasound radiography, radionuclide, magnetic resonance imaging, therapeutic procedures etc. [4]. An intern is expected to perform the aforementioned procedures under the supervision of well-trained, qualified and certified/licensed radiographers in accordance with the guidelines from RRBN either directly or indirectly. 
Direct supervision is done under the physical presence of the Radiographer, during the conduct of any procedures. He reviews the procedure in relation to the intern's achievement, evaluates the condition of the patient in relation to the intern's knowledge, and reviews and approves the procedure and/or image. During indirect supervision the radiographer is immediately available to assist the intern regardless of the level of intern achievement [5]. This period which could be classified as a transitional period from studentship to professional practice, could come with some challenges thereby affecting the competency of graduates during full time practice. A report on the challenges of internship in general indicates that students lament over unpleasant experience before, during and on completion of internship [6]. These challenges, if not properly identified and tackled could cause the non-accomplishment of the main objective of internship. This is applicable to all professions with radiography not an exception. To the best of the researcher's knowledge; no study has been done within this locality to identify such challenges in Radiography. Therefore, this present study is aimed at identifying these challenges faced by intern radiographers in Northern Nigeria.

\section{Subjects and methods}

The present univariate descriptive survey study was conducted on 50 participants. These were Intern Radiographers trained in accredited health institutions in Northern Nigeria. A cluster sampling technique was adopted with two institutions randomly selected from each of the three geopolitical zones (clusters) in the North. The questionnaire was designed using reports from previous similar surveys. The questionnaire was a 34-item structured one, designed to identify the challenges faced by intern radiographers. The first part of the questionnaire included the participant's demographic details, and the second part included questions to assess challenges in training/practice. The $3^{\text {rd }}$ and $4^{\text {th }}$ parts were dedicated to assessing challenges related to welfare and mentorship respectively. The questionnaires were sent with a cover letter stating the objectives of the study and that participation was voluntary. Participants were made to consent to participation and all questionnaires were anonimized. Also a standard interview guide was used to interview the chief interns of the participating hospitals to assess facilities, manpower, and practice. All responses were extracted, grouped and analyzed using the statistical package for social sciences (SPSS) 16.0 (IBM, New York, USA), where descriptive statistics such as frequency counts, mean, and percentage were generated and the results presented on tables and figures.

\section{Results}

A total number of 55 questionnaires were distributed, 50 were accepted and returned giving a response rate of $85.7 \%$. This consisted of 31 (62\%) males and 19 (38\%) females, with age range of 21-30 years (mean or 26 years $+/-2.74 \mathrm{SD}$ ) (See table 1 for participants demographics).

Table 1: Demographic Data of Participants

\begin{tabular}{|c|c|c|}
\hline VARIABLES & FREQUENCY & PERCENTAGE (\%) \\
\hline \multicolumn{3}{|l|}{ SEX } \\
\hline Male & 31 & 62 \\
\hline Female & 19 & 38 \\
\hline \multicolumn{3}{|c|}{ AGE RANGE (YEARS) } \\
\hline $21-25$ & 12 & 24 \\
\hline $26-30$ & 38 & 76 \\
\hline \multicolumn{3}{|c|}{ Distribution of respondents based on where they were trained } \\
\hline BUK & 6 & 12 \\
\hline UNEC & 2 & 4 \\
\hline UNIMAID & 32 & 64 \\
\hline UNN & 10 & 20 \\
\hline \multicolumn{3}{|c|}{ Distribution of Interns Based on Internship Placement } \\
\hline UMTH, Borno State & 7 & 14 \\
\hline AKTH, Kano & 14 & 28 \\
\hline ABUTH, Kaduna & 8 & 16 \\
\hline NHA, Abuja & 8 & 16 \\
\hline JUTH, Plateau & 6 & 12 \\
\hline FUTH, Gombe & 7 & 14 \\
\hline
\end{tabular}


Table: 2 Challenges Before Commencement of Internship

\begin{tabular}{|c|c|c|}
\hline VARIABLES & FREQUENCY & PERCENTAGE (\%) \\
\hline \multicolumn{3}{|c|}{ Time elapsed between induction and securing placement for Internship } \\
\hline 1-3 Months & 17 & 34 \\
\hline 4-7 Months & 17 & 34 \\
\hline 8-12 Months & 11 & 22 \\
\hline Above $1 \mathrm{yr}$ & 5 & 10 \\
\hline \multicolumn{3}{|c|}{ Time elapsed from completion of degree programme to being inducted by RRBN } \\
\hline 1-3 Months & 25 & 50 \\
\hline 4-7 Months & 17 & 34 \\
\hline 8-12 Months & 4 & 8 \\
\hline Above $1 \mathrm{yr}$ & 4 & 8 \\
\hline \multicolumn{3}{|c|}{ Was there any proper orientation programme organized by management at the start of internship? } \\
\hline Yes & 14 & 28 \\
\hline No & 36 & 72 \\
\hline
\end{tabular}

Table 3: Challenges During Internship

\begin{tabular}{|c|c|c|}
\hline VARIABLES & FREQUENCY & PERCENTAGE (\%) \\
\hline \multicolumn{3}{|c|}{ How long were you under supervision before being allowed to work without direct supervision? } \\
\hline$<1$ Month & 16 & 32 \\
\hline 1 Month & 23 & 46 \\
\hline 2 Months & 6 & 12 \\
\hline Not Applicable & 5 & 10 \\
\hline \multicolumn{3}{|c|}{ How long from start of internship before being placed to work alone during call? } \\
\hline$<1$ Month & 11 & 22 \\
\hline 1 Month & 23 & 46 \\
\hline 2 Months & 9 & 18 \\
\hline Not Applicable & 7 & 14 \\
\hline \multicolumn{3}{|c|}{ Are you paced on work rotation to various units? } \\
\hline Yes & 42 & 84 \\
\hline No & 8 & 16 \\
\hline \multicolumn{3}{|c|}{ How would you rate your level of satisfaction with the rotation practice in the department? } \\
\hline Excellent & 12 & 24 \\
\hline Good & 37 & 74 \\
\hline Very Poor & 1 & 2 \\
\hline \multicolumn{3}{|c|}{ How long from start of internship before being placed to work alone during call? } \\
\hline$<1$ Month & 11 & 22 \\
\hline 1 Month & 23 & 46 \\
\hline 2 Months & 9 & 18 \\
\hline Not Applicable & 7 & 14 \\
\hline \multicolumn{3}{|c|}{ Rating for rate of satisfaction with supervision } \\
\hline Adequate & 14 & 28 \\
\hline Moderately Adequate & 26 & 52 \\
\hline Inadequate & 8 & 16 \\
\hline Grossly Inadequate & 2 & 4 \\
\hline \multicolumn{3}{|c|}{ Rate the level of satisfaction with radiation protection accessories and working environment } \\
\hline Very Satisfied & 8 & 16 \\
\hline Satisfied & 31 & 62 \\
\hline Dissatisfied & 10 & 20 \\
\hline Strongly Dissatisfied & 1 & 2 \\
\hline
\end{tabular}

Table 4: Radiological equipment available, faulty and accessible at the participating institutions

\begin{tabular}{llll}
\hline & Available (\%) & Non-Accessible (\%) & Accessible (\%) \\
\hline CT & 100 & 33.3 & 66.7 \\
MRI & 83.3 & 66.7 & 33.3 \\
Mammography & 100 & 33.3 & 66.7 \\
X-ray Unit & 100 & 00.0 & 100 \\
US & 100 & 83.4 & 16.6 \\
Fluoroscopy & 50 & 83.4 & 16.6 \\
CR & 33.3 & 83.4 & 16.6 \\
Angio Unit & 33.3 & 83.4 & 16.6 \\
Orthopanthomography & 16.6 & 00.0 & 100 \\
\hline
\end{tabular}


Table 5: Challenges with Welfare

\begin{tabular}{|lcc|}
\hline VARIABLES & FREQUENCY & PERCENTAGE (\%) \\
\hline Placement for Radiography Interns & 1 & 2.86 \\
\hline Conhess 7/3 & 23 & 65.71 \\
\hline Conhess 8/1 & 5 & 14.29 \\
\hline Conhess 8/2 & 6 & 17.14 \\
\hline Above Conhess 8/2 & 5 & 10 \\
\hline Rating for level of satisfaction with response of practicing radiographers towards Interns' Welfare & 64 \\
\hline Very Satisfied & 32 & 24 \\
\hline Satisfied & 12 & 2 \\
\hline Dissatisfied & 1 & \\
\hline Very Dissatisfied & \\
\hline Rating for level of satisfaction with response of Hospital Management towards welfare & \\
\hline Very Satisfied & 2 & 52 \\
\hline Satisfied & 26 & 42 \\
\hline Dissatisfied & 21 & 2 \\
\hline Very Dissatisfied & 1 & \\
\hline Are you provided with accommodation? & \\
\hline Yes & 20 & 40 \\
\hline No & 30 & 60 \\
\hline
\end{tabular}

Table 6: Mentorship

\begin{tabular}{|c|c|c|}
\hline VARIABLES & FREQUENCY & PERCENTAGE (\%) \\
\hline \multicolumn{3}{|c|}{ Distribution of Practicing Radiographers based on rank } \\
\hline Senior & 20 & 48.8 \\
\hline Principal & 12 & 29.3 \\
\hline Asst. Chief & 3 & 7.3 \\
\hline Chief & 3 & 7.3 \\
\hline Asst. Director & 3 & 7.3 \\
\hline Deputy Director & 0 & 0 \\
\hline \multicolumn{3}{|c|}{ Are there mentorship programs implemented in the department? } \\
\hline Yes & 13 & 26 \\
\hline No & 37 & 74 \\
\hline \multicolumn{3}{|c|}{ Reaction of Practicing Radiographers towards interns when interns struggle with procedures } \\
\hline Calmly & 26 & 52 \\
\hline Moderately Calm & 22 & 44 \\
\hline Abusively & 2 & 4 \\
\hline
\end{tabular}

\section{Discussion}

The identification of challenges around a particular concept is essential in the improvement of the concept in question. This was the central point of the present study, which was to identify the challenges encountered by intern radiographers in Northern Nigeria. Findings from the study show that majority of the respondents were males (62\% against $38 \%$ ), which could be linked with the low of girl child education in the region [7]. Majority of the interns were trained at the University of Maiduguri and may due to the institution being the university in the region to offer BSc programme. Only a small percentage of interns came from the southern part of the country, and this may be due to the state of insecurity in the North. Table 2 reveals that majority of the respondents $(72 \%)$ felt that they were not given proper orientation at the commencement of internship practice and $78 \%$ of them were supervised for a month only and less before being allowed to work alone during working and call duty hours without direct supervision. These may have a negative effect on the training with many of them taking longer time to perfect in performing certain radiographic procedures and this may affect their clinical skills during full time practice. Only $40 \%$ of the respondents were given radiation monitoring devices, for this reason many of them may not know the amount of radiation they received during the internship training period and this may predispose them to greater radiation hazards. A good percentage of the respondents $(84 \%)$ were placed on rotation to various units and $98 \%$ of them were satisfied with the rotation system in the department; however, some of the facilities though available were non-accessible to interns either due to faulty equipment or interns not allowed to touch the equipment. As a result of this, interns may have less experience in the use of some of the sophisticated imaging modalities on completion of internship. Table 5 shows interns responses on welfare. About $97 \%$ of the interns were placed on Conhess 8/1 and above; however, $42 \%$ were not satisfied with the response of hospital management towards their welfare as majority $(60 \%)$ were not offered accommodation but majority $(74 \%)$ were satisfied with attitude of practicing radiographers towards their welfare. Mentorship was found to be a matter of concern based on the findings. About $78.1 \%$ of the practicing radiographers in the region were on the rank of principal radiographer and below while the remaining $21.9 \%$ were on the rank of Assistant Chief and above. This is an indication that mentorship in the region is below par as mentorship is about highly experienced person mentoring the less experienced ones [8]. 


\section{Conclusion}

The study reveal that the major challenges faced by intern radiographers in this region are interrelated, which are inherent in training/practice, welfare and mentorship, though welfare is a bit optimal. The major challenge faced was poor mentorship programme, as there were very few top ranking radiographers in the region. A more robust periodic monitoring of internship centers by regulatory body was identified as the panacea for further improvement of the practice. This study is limited by the fact that analysis was done based on respondent's responses and some may not have given sincere responses

\section{References}

[1]. Students' Hand Book, Institute of Radiography; Radiographers Registration Board of Nigeria. 2012; Pp1-7

[2]. Radiographers Registration Board of Nigeria (RRBN) Act http://lawnigeria.com/lawsofthefederation/RADIOGRAPHERS-\%28REGISTRATION-ETC.\%29-ACT.html] [Accessed Feb 2016]

[3]. Australian institute of Radiography. Definition of internship; Internship in Radiography Profession. [Available at http://www.air.asn.au]. [Assessed 2/02/2016]

[4]. Student's Record of Clinical \& Practical Training, 2013. Institute of Radiography; Radiographers Registration Board of Nigeria. Department of Medical Radiography, University of Maiduguri.

[5]. Northampton Community College of Radiography Students' Handbook. [Available at htpp://www.northampton.edu]. [Assessed 26/01/2016].

[6]. Eyoh E. Students and challenges of internship, Vanguard Newspaper 2013 [Available at http://www.vanguarngr.com] [Assessed 26/01/2016]

[7]. A.K. Abdulkareem, Girl-Child Education in Nigeria, Policy Issues and Challenges. Work paper University of Ilorin, Ilorin, Nigeria. 2015 Doi: 10.13140/RG.2.1.2022.1280.

[8]. Mentorship [Available at http://www.thementra.com][Accessed 31/05/2016] 